\title{
Research on the Development of China's Regional Economic Integration from the Perspective of Global Value Chain
}

\author{
Jin Jun \\ School of Economics, Politics and Law, Wenshan University, Wenshan 663000, China \\ 1448429333@qq.com
}

Keyword: Regional economic integration; Global value chain; China's economy

\begin{abstract}
At present, the multilateral trading system formed by the WTO is suffering from the deepening of the division of labor in the global value chain. Regional trade organizations are in full swing, the original trade rules are facing reconstruction, and the world economic system is in changes. In China, economic integration has also formed great influences. Therefore, Therefore, to explore the changes in regional economic integration from the perspective of global value chains and the opportunity to reshape global value chains, China's strategy to comprehensively enhance the competitiveness of the country's industrial structure.
\end{abstract}

The global value chain has been affecting the world's production system and the world has changed the rules of international trade as a whole. Although the multilateral trading system formed by the WTO as the dominant era is still running, its "border" is unable to meet the global value chain and its demand for trade and governance, so more measures are required to serve the "border". And use this as a standard to establish a new trade zone. The international economic wave at present is in response to the latest requirements of the global value chain for international trade, and regional economic integration is gradually showing new features.China has always attached great importance to regional economic integration. In the face of the current economic tide, China has built a trade zone dominated by China to ensure the economic development of China and its allies.

\section{The changes that regional economic integration needs to make in the perspective of global value chains}

\subsection{Service trade}

The role of service trade in the global value chain is far beyond imagination. It is the central link of the entire value chain and the guarantee of interconnection between other links. The service industry is an input to the manufacturing industry. It can coordinate all aspects of the production process, increase the added value of the manufacturing industry and the competitiveness of the manufacturing industry. Breaking down trade barriers and reducing trade costs are the most direct impacts of trade liberalization. It can also promote the flow of knowledge, technology and personnel, and promote the continuous development of the producer service industry, allowing the structure of global value chains gradually optimize. So, for global value chains, the liberalization of service trade is quite important to it. This is also an important part of the current regional economic integration.

\subsection{Trade in goods}

The global value chain has a very obvious sub-work for countries. Different parts of the products are produced in different countries, but this means that the products need to cross national borders from the beginning to production, and the number of times is quite high. Compared with the previous division of labor, the global value chain will increase its cost because of the continuous cross-border, and the division of labor is more detailed than before. Under such circumstances, the tariffs imposed by countries even are lower, and the cost will increase due to the import of various products and trade barriers, which will have a very large impact on production cost, market competitiveness and sales price of commodities. But if trade barriers can be cut and tariffs be reduced, the trade cost will decrease, production cost and sales price of commodities will decline, and market competitiveness will increase accordingly. However, at present, the level of border management is low, and the regulation of import and export of goods is not strict. These will have a series of adverse effects on the global value chain, which will lead to an increase in the cost of 
production of goods. In the current division of labor system, international trade and the global economy are increasingly affected by trade facilitation measures. Therefore, it is necessary to improve the border environment and improve the circulation efficiency of goods, which can reduce the logistics costs and customs clearance of goods import and export. It can also reduce the time between supply and demand in the international market, and ensure the connection between the global value chain and ensure the normal operation of the global value chain.

\subsection{Post-policy aspects of border}

In the past division of labor, the production of goods was only carried out in one country, and national trade only needed to establish corresponding rules for the "border". However, with the formation of global value chains, many production links need to be carried out in different countries, and the original rules are no longer able to meet current needs. The extension of trade rules from the "border" has become a destined choice. The integration of national standards and trade rules will promote the advancement of regional economic integration. The formation of global value chains has many implications for the formation of new rules in international trade. Countries that participate in the value chain must use transparent trade policies if they want to obtain economic benefits from trade. Such policies are of greatly helpful to attract investment. It is to tell other countries that the integration of domestic rules with current trade rules will benefit your economic development, but the construction of a good business environment, the protection of intellectual property rights, the establishment of corresponding labor systems and standards are the issues that need to be considered and resolved in regional economic integration.

\section{The pace of China's economic development in the new era}

\subsection{Review the situation, chase the pace of the times}

China should accurately grasp the two major development trends of globalization and regional economic integration presented to the world economy. At present, due to the influence of global value chains, international trade rules are gradually developing to higher levels and broader fields. Interpreting TPP (or TTIP) trade agreements is the currently top priority. It is ecause only by having a sufficient understanding of the new international situation, can China make a correct response and implement a corresponding strategy such as the "Belt and Road" that suits China's national conditions, and plan for the future development of China. Understand the gaps with developed countries such as the United States and Japan, and prepare for all the changes. There are some free trade zones in China. This is an important way for China to understand foreign trade rules. These free trade zones can also become pilot areas for China's economic and foreign trade rules, so as to observe the gap between China and developed countries. Make timely improvements based on the own deficiencies.

\subsection{Carry out reform and opening up}

Firstly, while carrying out a comprehensive economic transformation and upgrading, China must help let the less developed countries in the early stage of industrialization have the opportunity to catch up with a new wave of economic globalization and lay a good foundation for future regional economic integration. At the same time, keep optimizing China's own industrial structure to improve the comprehensive competitiveness and the comprehensive national strength of Chinese enterprises. Also, improve China's investment environment and provide direction and impetus for the formation of economic regional integration.

Secondly, China is currently building an open economic system to carry out reforms in the area of regional economic integration. Currently, the international trade rules have a tendency to expand from "border" to "inland", which has changed in many aspects, such as environment, labor and intellectual property, etc. This is similar to the current reforms in China. Therefore, the goal of opening up our market will be achieved with the help of this reform.

2.3 Establish the trade area dominated by China

Establishing a trade area dominated by China can not only win the initiative in China's re-enactment of international trade regulations, but also promote the establishment of a new domestic open economy system. It can also offset the adverse effects of similar TPPs on China. 
China needs to change its role positioning, from the participants in the original international trade regulations to the leader, and establish a trade area with China as the core. In the meanwhile, it can also form a China-led regional economic and trade partnership as soon as possible, forming a number of trade development rules probable for emerging economies. China is the largest developing country and needs to voice and gain more power for developing countries. So, China needs the dominance of international rules. This is not only the needs of China, but also the needs of developing countries.

\section{References}

[1]Fan Maoqing , Huang Wei. Research on the Evolution of China's Trade Industry Structure Based on Global Value Chain Decomposition [J]. World Economy,2014,(2):77-78

[2]Li Hongyan ,Wang Lan. Trade Benefits from the Perspective of Global Value Chain: A Review of Research Progress [J]. International Trade Issues,2015,(5):64-65

[3]Tian Chunhua. Regional Economic Integration and the Establishment of the Global Free Trade System [J].World Economy,1996,(12):69-70 